"State tax policy of insurance companies on different stages of insurance market development"

\begin{tabular}{ll} 
AUTHORS & $\begin{array}{l}\text { Anton Boyko } \\
\text { Liudmyla Ostapenko } \\
\text { Oleg Markin }\end{array}$ \\
\hline ARTICLE INFO & $\begin{array}{l}\text { Anton Boyko, Liudmyla Ostapenko and Oleg Markin (2016). State tax policy of } \\
\text { insurance companies on different stages of insurance market development. } \\
\text { Insurance Markets and Companies, } 7(1), 25-30 . \text { doi:10.21511/imc.7(1).2016.03 }\end{array}$ \\
\hline DOI & http://dx.doi.org/10.21511/imc.7(1).2016.03 \\
\hline RELEASED ON & Friday, 18 November 2016 \\
\hline JOURNAL & "Insurance Markets and Companies" \\
\hline FOUNDER & LLC "Consulting Publishing Company "Business Perspectives"
\end{tabular}

NUMBER OF REFERENCES

0

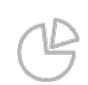

NUMBER OF FIGURES

0

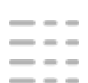

NUMBER OF TABLES

0

(C) The author(s) 2022. This publication is an open access article. 
Anton Boyko (Ukraine), Liudmyla Ostapenko (Ukraine), Oleg Markin (Ukraine)

\title{
State tax policy of insurance companies on different stages of insurance market development
}

\begin{abstract}
Peculiarities of taxation of insurance companies in Ukraine and Europe have been researched. Methodological principles determining the optimal level of tax burden for insurers, depending on the level of national insurance market development have been proposed. The forms of constructive and destructive effects of taxes on insurance companies functioning in the stages of development of the insurance market have been established.
\end{abstract}

Keywords: insurance companies, tax, tax burden, income tax, optimization, mathematical formalization.

\section{Introduction}

Peculiarities of state regulation of economy formed two basic impact directions on the activity of economic agents and financial services market conditions. The first includes the tools of monetary policy, the second - of fiscal policy. Implementation tools of these policies differ in the duration of impact, speed and cost effects resulting application. Regarding fiscal policy instruments, such as tax rates, for any financial market, it is leverage of long-term exposure to development dynamics of its subjects. Using different levels of tax burden, the state adjusts the volume of financial resources that remain at the disposal of financial intermediaries and directed to the state budget. That state regulatory authorities thereby affect investment activity and development dynamics of business entities.

Insurance companies' taxation differs greatly from the taxation of other business entities. It is connected with the specific peculiarities of its activity, which include the protection of property and other interests of insurers and profit opportunities through non-core activity (investment of insurance reserves). However, insurance companies' preferential taxation which is very often used in different countries, leads to its usage for tax avasion by other entities. This necessitates the formation of insurance companies system of taxation of income and profits, which we believe should be based not only on the differentiated tax rates and the tax base, but also on the transformation of the insurers' tax system depending on the stage of the national insurance market development.

\section{Analysis of the recent research and publications}

Peculiarities of insurance companies taxation are investigated in the accounts of Ernst \& Young

\footnotetext{
(C) Anton Boyko, Liudmyla Ostapenko, Oleg Markin, 2016.

Anton Boyko, Ph.D. in Economics, Assistant Professor of Economic Cybernetics Department, Sumy State University, Ukraine.

Liudmyla Ostapenko, Ph.D. in Economics, Director of Limited Liability Company "Consulting Publishing Company "Business Perspectives", Ukraine.

Oleg Markin, Ph.D. Student of Sumy State University, Ukraine.
}

(Global Insurance Premium Tax, 2015), German Insurance Association (GDV) (Indirect taxation on insurance contracts in Europe, 2015), Deloitte (2015, 2016), QBE (What Brexit means for business). In Ukraine the taxation system of insurance market business entities was investigated by O. Gamankova, V. Khlivnyi (2012), K. Reznichenko, I. Samofat (2015), V. Bazylevych, R. Pikus (2008), M. Khudiev (2005). Business processes formalization mathematical tools are reflected in the works of O. Kozmenko (2013), O. Kuzmenko (2014), V. Roenko (2014).

\section{Earlier unresolved parts of the problem}

The majority of researchers describe the existing changes in the insurance companies' taxation system expressing their own thoughts concerning the effectiveness of this or that approach. Not enough attention is paid towards the development of methodological principles of optimal taxation incidence for insurance companies and its differentiation depending on the level of national insurance market development.

\section{Goal of the research}

Methodological bases development for determining taxation incidence for insurers depending on the level of insurance market development.

\section{The main results of the research}

Not focusing on definite time intervals with specific efforts of state authorities to change the insurance companies' taxation system in Ukraine, from 1997 till 2016, we declare that until 2015, national insurers in their majority held special preferential taxation regime. And the main tax they paid was gross premiums tax that included 3\%. Besides, taxation base for this tax was lessened on the premium volume given for reinsurance. For all other insurance company incomes, existing mechanism of income tax payment was applied (tax rate at different times in Ukraine was between 18\%-30\%). From January 1, 2015, insurers in Ukraine were transmitted on a general taxation system, though 
stayed on an existing 3\% gross premium tax. Thus, taxation system reform in Ukraine was held as an enforcing fiscal taxation function, which is impossible in crisis periods.

Summarizing the peculiarities of insurance companies' taxation in Ukraine (tax base formation mechanism, preferential kinds of insurance, ways towards reinsurance taxation operations and so on), we formalize the systems of destructive and constructive tax impact on the insurance market functioning on different development levels (Table 1).

Table 1. Taxation instruments impact on insurance market

\begin{tabular}{|c|c|c|c|}
\hline $\begin{array}{l}\text { Insurance market } \\
\text { development stage and its } \\
\text { characteristics }\end{array}$ & Taxation instruments & Constructive impact & Destructive impact \\
\hline \multirow{3}{*}{$\begin{array}{l}\text { 1. Formation (determining } \\
\text { conditions creation and } \\
\text { insurance companies' future } \\
\text { activity) } \\
\text { 2. Make-up (active enlargement } \\
\text { of insurance companies } \\
\text { quantity with different } \\
\text { licenses) }\end{array}$} & Profit tax rate & Gross premiums are taxed only at low rate & High tax rates for gross premiums \\
\hline & $\begin{array}{l}\text { Preferential taxation of definite } \\
\text { kinds of insurance }\end{array}$ & $\begin{array}{l}\text { All kinds of life and compulsory insurance are } \\
\text { taxed on a zero rate }\end{array}$ & Preference absence \\
\hline & $\begin{array}{l}\text { Taxation base and reinsurance } \\
\text { operations place determining }\end{array}$ & $\begin{array}{l}\text { Gross premiums minus premiums sent for } \\
\text { reinsurance are taxed, with further rating to } \\
\text { reinsurers non-residents }\end{array}$ & $\begin{array}{l}\text { All gross premiums including } \\
\text { premiums on reinsurance operations } \\
\text { are taxed, no ratings for reinsurers } \\
\text { non-residents are applied. }\end{array}$ \\
\hline \multirow{3}{*}{$\begin{array}{l}\text { 3. Development (a significant } \\
\text { number of companies, } \\
\text { including with foreign capital, } \\
\text { the formation of the branch } \\
\text { network, providing various } \\
\text { types of insurance) }\end{array}$} & Profit tax rate & $\begin{array}{l}\text { The largest from two rates is chosen: gross } \\
\text { premium (3\%-5\%) or income (15\%-20\%) }\end{array}$ & $\begin{array}{l}\text { High income tax rates or its } \\
\text { simultaneous usage }\end{array}$ \\
\hline & $\begin{array}{l}\text { Preferential taxation of definite } \\
\text { kinds of insurance }\end{array}$ & $\begin{array}{l}\text { All kinds of life and compulsory insurance are } \\
\text { taxed on a zero rate }\end{array}$ & Preference absence \\
\hline & $\begin{array}{l}\text { Taxation base and reinsurance } \\
\text { operations place determining }\end{array}$ & $\begin{array}{l}\text { Gross premiums are calculated except } \\
\text { premiums sent to highly ranked reinsurers, and } \\
\text { income by International Accounting Standards } \\
\text { methods }\end{array}$ & $\begin{array}{l}\text { Income taxation is transmitted } \\
\text { through special state authorities } \\
\text { created methodology, which is not } \\
\text { correlated with accounting }\end{array}$ \\
\hline \multirow{3}{*}{$\begin{array}{l}\text { 4. Peak functioning (market } \\
\text { consolidation, clearing it from } \\
\text { circuit operations, significant } \\
\text { volume of insurers } \\
\text { investment income) }\end{array}$} & Profit tax rate & $\begin{array}{l}\text { Insurers' income with the rate not more than } \\
10 \% \text { is taxed }\end{array}$ & $\begin{array}{l}\text { Gross premiums or insurers' income } \\
\text { with the rate more than } 15 \% \text { are } \\
\text { taxed }\end{array}$ \\
\hline & $\begin{array}{l}\text { Preferential taxation of definite } \\
\text { kinds of insurance }\end{array}$ & $\begin{array}{l}\text { Absent taxes on insurance kinds, the tax is not } \\
\text { applied for income only, got from the reserves } \\
\text { on life insurance placement }\end{array}$ & Any taxes of insurance kinds \\
\hline & $\begin{array}{l}\text { Taxation base and reinsurance } \\
\text { operations place determining }\end{array}$ & $\begin{array}{l}\text { Insurer's income is calculated with the methods } \\
\text { of International Accounting Standards }\end{array}$ & $\begin{array}{l}\text { Taxation base formation is applied on } \\
\text { the basis of separate methodology }\end{array}$ \\
\hline \multirow{3}{*}{$\begin{array}{l}\text { 5. Crisis (insurance companies' } \\
\text { solvency loss, insurance } \\
\text { services' demand lessening, } \\
\text { investment income } \\
\text { lessening) }\end{array}$} & Profit tax rate & $\begin{array}{l}\text { Insurers income with the rate not more than } 5 \% \\
\text { is taxed }\end{array}$ & $\begin{array}{l}\text { Insurers income with the rate more } \\
\text { than } 10 \% \text { is taxed }\end{array}$ \\
\hline & $\begin{array}{l}\text { Preferential taxation of definite } \\
\text { kinds of insurance }\end{array}$ & $\begin{array}{l}\text { All kinds of life and compulsory insurance are } \\
\text { taxed on a zero rate }\end{array}$ & $\begin{array}{l}\text { Small quantity of preferential } \\
\text { insurance }\end{array}$ \\
\hline & $\begin{array}{l}\text { Taxation base and reinsurance } \\
\text { operations place determining }\end{array}$ & $\begin{array}{l}\text { Insurer's income is calculated with the methods } \\
\text { of International Accounting Standards }\end{array}$ & $\begin{array}{l}\text { Taxation base formation is applied on } \\
\text { the basis of separate methodology }\end{array}$ \\
\hline \multirow{3}{*}{$\begin{array}{l}\text { 6. Transformation (insurance } \\
\text { companies' functioning on } \\
\text { the basis of anti crisis } \\
\text { legislation, new insurance } \\
\text { products and its trading ways } \\
\text { appearance) }\end{array}$} & Profit tax rate & $\begin{array}{l}\text { Insurers income with the rate not more than } 5 \% \\
\text { is taxed }\end{array}$ & $\begin{array}{l}\text { Insurers income with the rate more } \\
\text { than } 10 \% \text { is taxed }\end{array}$ \\
\hline & $\begin{array}{l}\text { Preferential taxation of definite } \\
\text { kinds of insurance }\end{array}$ & $\begin{array}{l}\text { IT sphere risks and other high technology } \\
\text { spheres }\end{array}$ & $\begin{array}{l}\text { Traditional preferences: of life and } \\
\text { compulsory insurance }\end{array}$ \\
\hline & $\begin{array}{l}\text { Taxation base and reinsurance } \\
\text { operations place determining }\end{array}$ & $\begin{array}{l}\text { Insurer's income is calculated with the methods } \\
\text { of International Accounting Standards }\end{array}$ & $\begin{array}{l}\text { Taxation base formation is applied on } \\
\text { the basis of separate methodology }\end{array}$ \\
\hline
\end{tabular}

At the insurance market development stages, state tax policy should be directed on the organization of most appropriate basis for insurance framework of organization. Only preferential tax status of insurance sphere will let attract great private financial resources into this sphere. That is, on this stage of insurance market development, there should be identical tax rate of gross premiums in the volumes not more than 5\% and exemption of most socially oriented kinds of insurance, for instance, medical insurance, retirement insurance, "Green card" and others. Besides, on the make-up stage of insurance market, only premiums transmitted into reinsurance by high rated reinsurers should be free from taxation, as this will let the opportunity to lessen corruption operations volume.
On the insurance market development stage, insurers' income taxation system should be introduced, even with parallel existence of gross premiums taxation system. It will give the possibility for insurers to adapt to taxation changes. This is due to the insurance services' classical market formation need, and not for usage of differences in insurance companies' taxation methods with the aim of taxation payment optimization by the last. There may exist two taxation systems at once: both gross premiums and insurers' income, but insurance companies should pay the largest from them. It will give the possibility to start "clearing" the insurance market from circuit operations. Reinsurance should be paid great attention, as insurers actively use this instrument not 
only for own risks minimization, but also for getting costs abroad. Thus, form the gross premiums taxation base only premiums given to high rated reinsurers and with fine reputation should be deducted. Further state regulation authorities should pay attention to the work history of this or that reinsurer and reinsurance object, as financial medium rate is not the proof of its decent activity, as the 2007-2008 crisis showed. At the same time, income before insurance company taxation should be calculated exceptionally by International Accounting Standards methodology, as some other methodology will not only worsen the calculation from the point of definite articles' content unclearness, but also will give the insurers opportunity to rise their own expenses and, at the same time, to form the loss from activity, and, therefore, not to pay taxes.

Insurance market development peak should be accompanied by minimal tax burden. This will provide the insurance companies to be at this stage for a long period of time, and to get great amounts of tax revenues for a state due to economies of scale. There shouldn't be preferential taxation at all, as this deforms the market and creates unequal competitive bids. At the same time, the income the insurer gets from placing reserves formed on the basis of premiums got from life and compulsory insurance should be free from taxation. This will give the possibility to activate the part of insurance activity even more.

During insurance market crisis, taxation level should be lessened, and preferential insurance types should be widened. At this stage, the main essence of state regulation authorities is the support of insurance companies' solvency by all possible instruments, including tax. But insurance activity monitoring from the point of specially authorized state entity should rise not to let the insurance market state worsening by getting tax preferences.

Insurance market transformation is indispensible after crisis, it is connected with both new conditions of economic management of all economic agents, and innovation activity types appearance, with the specific risks. In these conditions, insurers' state taxation policy should be in a small taxation burden, to provide the possibility for insurance companies to renew from the actions of crisis factors destructive actions. Risks connected with IT sphere and highly technological companies should be taxed on a zero rate to get innovative sphere towards insurance not overvaluing insurance rates for the high income tax rate.
Besides, it should be stated after transformation insurance market begins again a new life cycle, but with different conditions and activity peculiarities.

It should be noted the special preferential taxation regime of insurance companies' activity leads to large usage volume of their operations with the aim of taxation avoidance and costs legalization got in illegal way. However, insurance companies' activity development without preferential taxation policy is impossible at the beginning stages of insurance market make up.

For Ukraine, the most serious problems connected with taxation system of insurance market agents are:

- double taxation (the tax is levied on income and profits);

- insurance types list, which are taxed at a zero rate. Except life insurance, retirement, "Green card" and some other compulsory insurance types, the actuality of adding into preference category health insurance requires;

- the forming mechanism of taxable income. The parts of profits and expenses articles of insurance companies should be decoded more precisely, that are used for income taxation determining;

- procedure of insurance reserves inclusion to the taxation base. Insurance reserves costs should work for economy of Ukraine as investment, that's why they shouldn't be taxed;

- reinsurance operations taxation specific. State regulation of reinsurance operations should take place not through taxation instruments, but on the basis of detailed monitoring of reinsurance agent and the image of cessionaire and retrocessionaire companies;

- taking into account the expenditures on insurance towards enterprises' gross expenditures. Except expenditures of financial risks all other types of insurance should form the other expenditures' article of enterprises and lessen taxable income.

Exploring the system of insurance companies' income taxation in European countries, for instance, Germany, we state that for that country insurance premiums taxation and difference attitude towards each insurance type of taxation is characteristic. There take place different rates and preference regimes, as life and health insurance and reinsurance get free from taxation. For fire and fire business interruption insurance, the largest taxation rate is featured on the level of $22 \%$ of insurance premiums. The basic is the tax rate of $19 \%$ of insurance premiums, it is used towards residential building, home contents, individual accident, goods in transit 
insurance in Germany and most part of other types of insurance. Lowered taxation rate of insurance premiums in Germany exists for marine hull (3\%) and hail $(0.3 \%)$.

The common taxation system of insurance companies is in Great Britain. Only basic is the rate of $6 \%$ from insurance premiums, for such types of insurance as fire, private medical insurance and others. Higher taxation rate in the amount of $20 \%$ is applied to travel and certain extended warranty and mechanical breakdown. Life and pensions, marine, aviation and transport (MAT), export credit, reinsurance are free from profit taxation rate.

That is, for Germany and Great Britain, the established insurance taxation profit system is characteristic. Based on the fact that in these countries, insurance system with absence usage of insurance companies for criminal profits legalization is developed, getting profit from investment activity, then, the insurance premiums taxation is applied.

For countries with less developed insurance system a bit different situation is found. For example, the features of Hungary include the rate of insurance premiums taxation changes depending on the sum of earned premiums during last year. Thus, in case of getting the last year volume of premiums in the amount of 8 and more milliards of forint, the taxation rate is $10 \%-15 \%$, in case of premiums volume of more than 700 million forint, the tax rate is $5 \%$ or $7.5 \%$, in case of earned premiums amount is less than 700 million forint, the tax rate is 2.5 or $3.75 \%$. These taxation rates are applied to all insurance types, except life, health, agricultural risk and reinsurance, which are free from taxation.

Poland realizes insurers' taxation with the help of income tax. Insurers' income is taxed on general terms with $19 \%$ rate. This fact approves the actuality to introduce the same system in Ukraine, as Poland is considered to be the etalon country for Ukraine in all financial-economic issues on the integration stage to European Union.

Thus, the taxation burden level is different in every country, both taxation base and insurance types and rates are differentiated. However, taking into account the tendency of insurers from undeveloped countries to financial and criminal breach of law, the most actual is profit taxation at this stage. At the same time, effective taxation rate of insurers should bear clear analytical framework.

Thus, optimal insurers' income tax rate determining depending on the insurance market development stage should be tackled on the basis of mathematical programming usage. To formalize this approach, it is proposed to introduce:
- purposive function - regressive equation depending on the ratio of gross premiums to GDP from factor features of income tax rate, insurers' assets, insurance companies' quantity. This purposive function formation is caused by the most representative feature that describes insurance market development is the gross premiums ratio to GDP, it shows the volume of this market and its importance for state economy. Factor variables also quantitatively describe the insurance market state, assets volume characterizes, to some extent, financial solvency of its agents, and companies' quantity - market concentration and insurers' market power, as comparing to assets, it is possible to make a conclusion about great amount of captive and low solvency companies' functioning;

- controlled input variable - income tax rate, which is a search variable;

- limitation - first, the level of insurance benefits as econometric dependence model on income tax rate. The value of insurance benefits level directs to the singular meaning. This limitation is due to the fact the insurers must actively do their basic function on interests' defense of insurers and make payments. Second, tax returns as regressive dependence equation on income tax rate. The value of tax return is the index destimulator concerning controlled input variable, that is, there should be a regressive insurers' income tax rate, the more they get profit, the less is the rate. Third, investment profit as econometric dependence model on income tax rate. Investment rate value research as a stimulator concerning controlled input variable, is due to the need to activate effective insurers' work on investment market. Fourth, the relation of reinsurance volume among nonresidents to reinsurance volume among residents as a regressive dependence equation on income tax rate. The value of this parameter should be less than one, as prevalence in national risks reinsurance among non-residents indicates the costs withdrawal abroad.

Mathematical record of this approach is the following:

$$
\begin{aligned}
& \frac{G P}{G D P}=a_{0}+a_{1} \cdot T R P+a_{1} \cdot A I+a_{2} \cdot N I C \rightarrow \max ; \\
& \left\{\begin{array}{l}
L P=l_{0}+l_{1} \cdot T R P \leq 1, \\
T R=t_{0}+t_{1} \cdot T R P \geq \overline{T R} \\
P I=p_{0}+p_{1} \cdot T R P \geq \overline{P I} \\
R R=r_{0}+r_{1} \cdot T R P<1
\end{array}\right.
\end{aligned}
$$


where $G P$ - gross premiums; $G D P$ - gross domestic product; TRP - profit tax rate; $A I$ insurers' assets; NIC - insurance companies number; $L P$ - insurance profits level; $T R$ - tax returns; $P I$ - investment profit; $R R$ - the relation of reinsurance volume among non-residents to reinsurance volume among residents; $\overline{T R}-$ the average value of tax returns for the analyzed period of time; $\overline{P I}$ - average income value from investment for the analyzed period of time.

It is an adaptive model, which means it should be calculated in a half year interval for each group of insurance companies: small, medium and large. The proposed approach usage shouldn't be in all cases, as it takes into account average parameters on investment profit and tax returns, and these parameters among different in volume companies cannot be compatible. This will create the possibility to continuously review income tax rate depending the direction of insurance market and definite groups of its agents. That is whether insurers increase investment activity, use reinsurance operations for costs legalization and on which level the enjoyment level of insurance demands is placed. If these parameters have positive dynamics in time or correspond to standards, then, income tax rate will lessen, if insurance market does not execute its function, then, on the contrary, it will increase.

The difficulty of insurer's income optimal tax rate determining approach depending on the insurance market development stage means constant monitoring of the insurance market situation for a definite group of companies and tax rate change for half year (establishing of accounting for half a year), however, in our case, it will be a stimulating instrument of state tax policy, which will let tackle burning for a definite insurance market development stage issues.

Testing of earlier proposed approach on evidence of insurance market of Ukraine lets get the following equation system:

$$
\begin{aligned}
& \frac{G P}{G D P}=0.67+0.43 \cdot T R P^{2}-2.57 \cdot T R P+ \\
& +0.22 \cdot \ln (A I)+0.08 \cdot N I C^{2}+0.97 \cdot N I C \rightarrow \max ; \\
& \left\{\begin{array}{l}
L P=2.97+4.59 \cdot T R P^{2}+1.36 \cdot T R P \leq 1, \\
T R=0.35-0.02 \cdot T R P \geq \overline{T R} \\
P I=59863.59-15.26 \cdot T R P \geq \overline{P I,} \\
R R=4895.57+0.59 \cdot \ln (T R P)<1 .
\end{array}\right.
\end{aligned}
$$

Modeling task determining of optimal income tax rate level and its solution with the help of simplex method let get an optimal level of analyzed parameter on the level of $30 \%$. We didn't divide the insurance companies into groups. All insurance companies are insignificant in assets volume with low solvency. Got high income tax meaning is also totally validated, as, among four limitations, only limitation concerning value relation of reinsurance volume among non-residents to reinsurance volume among residents is executed. At the same time, neither profits level, nor tax returns lead to optimal meaning.

\section{Conclusion}

Tax instruments for insurance market have crucial importance and are able to activate not only insurance companies' activity, but also insurance services extension level among individuals and legal entities in the country. However, state policy should use taxation system not from the fiscal point, but as a mechanism to stimulate economic processes in the country. The main development vector for Ukrainian insurance market should become effective insurers' income tax rate depending on the insurance returns' level, usage peculiarities of reinsurance operations and tax returns of insurance companies. Besides, with every next stage of insurance market development, taxation system should be transformed and directed on the increase of not the volume of tax burden on insurers, but their investment activity and insurers' defense.

\section{References}

1. Bazylevych, V.D., Bazylevych, K.S., Pikus, R.V. et al. (2008). Insurance. Bazylevych, V.D. (Ed.). K.: Znannia, 1019 p. [in Ukrainian].

2. Boyko, A., Roienko, V. (2014). Risk assessment of using insurance companies in suspicious transactions, Economic Annals, Vol. 21 (11-12), pp. 73-76.

3. Hamankova, O.O., Khlivnyi, V.K. (2012). Podatok na prybutok strakhovykiv: shliakhy vdoskonalennia [Income tax of the insurers: way of improvement]. Pavlenko, A.F. (Ed.). Vcheni zapysky: zb. nauk. prats [Proceedings: collection of research papers]. Ministry of Education and Science of Ukraine, SHEI "Kyiv nat. econ. univ. named after Vadym Hetman. Kyiv: KNEU, vol. 14, part 1, pp. 153-157 [in Ukrainian].

4. Indirect taxation on insurance contracts in Europe. (2015). GDV. Available at: http://www.en.gdv.de/wpcontent/uploads/2015/05/InsuranceEurope_Indirect-Taxation-on-Insurance-Contracts-in-Europe-2015.pdf.

5. Global Insurance Premium Tax (IPT) Newsletter. (2015). Ernst \& Young, 2. Available at: http://www.ey.com/Publication/vwLUAssets/EY-global-insurance-premium-tax-ipt-newsletter/\$FILE/EY-globalinsurance-premium-tax-ipt-newsletter.pdf. 
6. Kozmenko, O., Roienko, V. (2013). Evaluation and use of indicators of insurance companies' investment activities, Investment Management and Financial Innovations, Vol. 10, pp. 98-105.

7. Khudiev, M.M. (2005). Udoskonalennia mekhanismu opodatkuvannia u strakhovykh orhanizatsiiakh [Improvement of taxation mechanism in insurance organizations], Finansy [Finance], 5, pp. 64-66 [in Ukrainian].

8. Kuzmenko, O.V. (2014). Ekonomiko-matematychne zabezpechennia funktsionuvannia perestrakhovoho rynku [Economic and mathematical provision of the reinsurance market]. Monograph. Sumy: Universytetska knyha, 430 p. [in Ukrainian].

9. Reznichenko, K.G., Samofat, I.S. (2015). Osoblyvosti opodatkuvannia strakhovykh kompanii v Ukraini [Peculiarities of taxation of insurance companies in Ukraine], Collection of research papers of National University of State Tax Service of Ukraine, 1, pp. 143-154 [in Ukrainian]. Available at: http://nbuv.gov.ua/UJRN/ znpnudps_2015_1_15.

10. Shirinian, L.V. (2010). Opodatkuvannia strakhovykh kompanii Ukrainy [Taxation of insurance companies of Ukraine], Finansy Ukrainy [Finance of Ukraine], 5, pp. 76-85 [in Ukrainian].

11. Taxation And Investment In Hungary. (2015). Deloitte. Available at: https://www2.deloitte.com/content/dam/Deloitte/global/Documents/Tax/dttl-tax-hungaryguide-2015.pdf.

12. Taxation and Investment in Ukraine. (2016). Deloitte. Available at: https://www2.deloitte.com/content/dam/Deloitte/global/Documents/Tax/dttl-tax-ukraineguide-2016.pdf.

13. Taxation and Investment in United Kingdom. (2015). Deloitte. Available at: https://www2.deloitte.com/content/dam/Deloitte/global/Documents/Tax/dttl-tax-unitedkingdomguide-2015.pdf.

14. What Brexit means for business. (2016). QBE. Available at: http://www.qbeeurope.com/documents/research/What $\% 20$ Brexit $\% 20$ means $\% 20$ for $\% 20$ business.pdf. 